\title{
PEMBENTUKAN PROVINSI KALIMANTAN UTARA (1999-2012)
}

\author{
THE ESTABLISHMENT OF NORTH KALIMANTAN \\ PROVINCE (1999-2012)
}

\author{
Joshua Jolly Sucanta Cakranegara \\ Departemen Sejarah, Fakultas Ilmu Budaya, Universitas Gadjah Mada \\ Bulaksumur, Yogyakarta, 55281, Indonesia \\ joshua.jolly.s.c@mail.ugm.ac.id
}

Diterima tanggal 20 Juli 2020

Disetujui tanggal 27 Oktober 2020

\begin{abstract}
North Kalimantan Province (Kaltara) is the $34^{\text {th }}$ province or the youngest province in Indonesia. The establishment of the province is inseparable from long historical dynamics. This can be seen from the period of the establishment of the Bulungan Sultanate, the Dutch East Indies colonial government, the Japanese occupation government, until the Indonesian government. By applying historical approach, this paper aims to explain the historical dynamics of the establishment of North Kalimantan Province after 1998, since regional autonomy strengthened in 1999 through Law Number 22 of 1999 on Regional Government to the final establishment through Law Number 20 of 2012 on Establishment of North Kalimantan Province. The results of this study indicate that the establishment of the province cannot be separated from the spirit of regional autonomy that was intensified after 1998. In addition, a number of multidimensional studies in the social-economic, natural resource management, defense-security, and territorial fields have become a strong foundation for the establishment of the province. Thus, political processes, both at the central and regional levels, as well as in-depth study and great local community support were key factors in the establishment of North Kalimantan Province. This become a historical dynamic in the history of regional government in the Unitary State of the Republic of Indonesia (NKRI).
\end{abstract}

Keywords: North Kalimantan Province, regional autonomy, multidimensional study, political process, and history of regional government.

\begin{abstract}
ABSTRAK
Provinsi Kalimantan Utara (Kaltara) merupakan provinsi ke-34 atau provinsi termuda di Indonesia. Pembentukan provinsi ini tidak terlepas dari dinamika historis yang panjang. Hal ini dapat dilihat dari periode berdirinya Kesultanan Bulungan, pemerintah kolonial Hindia Belanda, pemerintah pendudukan Jepang, hingga pemerintah Indonesia. Dengan pendekatan sejarah, tulisan ini bertujuan memaparkan dinamika historis pembentukan Provinsi Kalimantan Utara setelah 1998, yakni sejak otonomi daerah menguat pada 1999 melalui Undang-Undang Nomor 22 Tahun 1999 tentang Pemerintahan Daerah hingga pembentukan final melalui Undang-Undang Nomor 20 Tahun 2012 tentang Pembentukan Provinsi
\end{abstract}


Kalimantan Utara. Hasil penelitian ini menunjukkan bahwa pembentukan provinsi ini tidak dapat dilepaskan dari semangat otonomi daerah yang digencarkan setelah 1998. Selain itu, sejumlah kajian multidimensional dalam bidang sosial-ekonomi, pengelolaan sumber daya alam, pertahanan-keamanan, dan kewilayahan telah menjadi landasan kuat pembentukan provinsi ini. Dengan demikian, proses-proses politik, baik di tingkat pusat maupun daerah, serta pengkajian yang mendalam dan dukungan masyarakat setempat yang besar merupakan faktor kunci pembentukan Provinsi Kalimantan Utara. Hal ini pun menjadi sebuah dinamika sejarah tersendiri dalam sejarah pemerintahan daerah di Negara Kesatuan Republik Indonesia (NKRI).

Kata kunci: Provinsi Kalimantan Utara, otonomi daerah, pengkajian multidimensional, proses politik, dan sejarah pemerintahan daerah.

\section{A. PENDAHULUAN}

Provinsi Kalimantan Utara (Kaltara) merupakan provinsi ke-34 sekaligus provinsi termuda di Indonesia sampai saat ini. Provinsi ini terbentuk berdasarkan Undang-Undang Nomor 20 Tahun 2012 tentang Pembentukan Provinsi Kalimantan Utara. Pembentukan provinsi ini pun memiliki latar belakang historis yang panjang.

Pembentukan Provinsi Kalimantan Utara tidak dapat dipisahkan dari dinamika pembentukan Provinsi Kalimantan Timur. Hal ini didasarkan pada fakta bahwa sebelum menjadi provinsi yang berdiri sendiri, Provinsi Kalimantan Utara merupakan bagian dari Provinsi Kalimantan Timur. Pada waktu itu, Provinsi Kalimantan Timur menjadi provinsi terluas kedua di Indonesia setelah Papua.

Kalimantan Timur telah dikenal dalam narasi besar sejarah Indonesia. Hal ini tidak terlepas dari eksistensi Kerajaan Kutai (Mulawarman) yang diduga kuat menjadi kerajaan pertama di Indonesia (Nusantara). Kerajaan yang telah berdiri sejak abad ke-4 Masehi di tepi Sungai Mahakam ini menjadi kerajaan besar yang mendapat pengaruh Hindu India yang sangat besar. Di samping eksistensi Kerajaan Kutai Mulawarman, dikenal juga Kesultanan Kutai Kertanegara yang bercorak Islam, yang kemudian menaklukkan Kerajaan Kutai Mulawarman (Anonim 1992:17; Riwut 1958:45, 65).

Hampir sepuluh abad kemudian, di Kalimantan Timur bagian utara telah berdiri Kerajaan Berau yang memisahkan dari dari Kerajaan Kutai Mulawarman (Anonim 1992:21). Pada 1800 , terdapat kerajaan kecil yang memisahkan dari wilayah Kerajaan Berau, yaitu Kesultanan Bulungan. Kesultanan ini merupakan persatuan atas sejumlah kerajaan kecil yang berdekatan, seperti Suku Kenyah, Tidung, dan Bulungan (Anonim 1992:49).

Kesultanan Bulungan telah menarik perhatian, terutama Belanda, sejak abad ke-19. Konflik antara Kesultanan Bulungan dan Kerajaan Kenyah dimanfaatkan Belanda untuk menyatakan dukungannya terhadap Kesultanan Bulungan. Walhasil, 
Kesultanan Bulungan memenangkan pertempuran melawan Kerajaan Kenyah. Kemenangan ini harus dibayar dengan penandatanganan perjanjian antara Kesultanan Bulungan dengan Belanda pada 27 September 1834 yang menyatakan bahwa Kesultanan Bulungan mengakui Belanda sebagai yang dipertuan. Sejak saat itulah, Kesultanan Bulungan berada dalam cengkeraman hegemoni Belanda (Karim 2011:24).

Setelah itu, berdasarkan kontrak pendek (korte verklaring) antara Sultan Muhammad Amiril Kaharuddin dengan Belanda, Kesultanan Bulungan benarbenar jatuh ke tangan Belanda pada 12 November 1850 . Kontrak tersebut menyatakan bahwa Kesultanan Bulungan takluk kepada Belanda dan sebaliknya Belanda membantu menjaga keamanan wilayah Kesultanan Bulungan (Anonim 1992:45; Nurcahyani dan Juwono 2017:21-22). Hal ini tidak terlepas dari upaya kolonisasi Belanda untuk melawan hegemoni Inggris di Nusantara, khususnya di Kalimantan. Sepanjang abad ke-19, Kalimantan telah menjadi rebutan dua bangsa Barat, yaitu Inggris dan Belanda (Irwin 1986:13). Persaingan hegemoni ini pun berakhir dengan pembagian wilayah Kalimantan, yaitu pantai utara dikuasai Inggris serta pantai barat, selatan, dan timur dikuasai Belanda (Irwin 1986:273).

Setelah pemerintah kolonial Hindia Belanda menguasai Kalimantan, wilayah ini dibagi menjadi dua keresidenan, yaitu Keresidenan Kalimantan Barat (Westerafdeeling van Borneo) yang beribu kota Pontianak dan Keresidenan Kalimantan Selatan dan Timur (Zuider-en Oosterafdeeling van Borneo) yang beribu kota di Banjarmasin (Cabaton 2015:361-64). Wilayah yang dahulu merupakan kekuasaan Kesultanan Bulungan menjelma menjadi Afdeeling Bulongan (Bulungan) Berau dengan lima onderafdeeling (Riwut 1958:4). Lima onderafdeeling tersebut adalah Bulungan, Tarakan, Tanah Tidung, Apo Kayan, dan Berau (Anonim 1992:58). Onderafdeeling Bulungan dibagi ke dalam dua distrik, yaitu Distrik Bulungan dengan ibu kota Tanjung Palas dan Distrik Sesayap dengan ibu kota Sesayap. Distrik Bulungan membawahi tiga onderdistrict, yaitu Muara Pangean, Tarakan, dan Long Nawang, sedangkan Distrik Sesayap membawahi tiga onderdistrict, yaitu Sembakung, Mentarang, dan Kerayan (Anonim 1992:77).

Perkembangan masyarakat yang semakin pesat di Kalimantan Timur, khususnya di Onderafdeeling Bulungan, menyebabkan pemerintah kolonial Hindia Belanda mengatur lebih jauh tata wilayah pemerintahan di sana. Pada 1923, Onderafdeeling Bulungan memiliki empat distrik, yaitu Bulungan, Tarakan, Tanah Tidung, dan Apo Kayan. Distrik Bulungan membawahi Onderdistrict Tanjung Palas. Distrik Tarakan membawahi Onderdistrict Tarakan. Distrik Tanah Tidung membawahi Onderdistrict 
Malinau, Nunukan, Krayan, Sembakung, dan Mentarang. Distrik Apo Kayan membawahi Onderdistrict Apo Kayan (Anonim 1992:78).

Struktur wilayah administrasi pemerintahan demikian tetap bertahan hingga Belanda menyerah kepada Jepang pada 1942. Hal itu tidak terlepas dari upaya Jepang menguasai Asia Timur Raya dalam Perang Dunia II sejak 1941. Wilayah Kalimantan Timur merupakan wilayah awal Hindia Belanda yang diserang dan dikuasai Jepang, yaitu Tarakan (13 Januari 1942), Balikpapan (24 Januari 1942), dan Samarinda (3 Februari 1942) (Anonim 1992:86).

Setelah wilayah Hindia Belanda secara resmi diserahkan kepada Jepang, Jepang membentuk sistem administrasi pemerintahan yang serupa dengan masa pemerintah kolonial Hindia Belanda. Wilayah Kalimantan Timur dibagi ke dalam satuan administrasi pemerintahan sebagai berikut. Pertama, dua syu (keresidenan), yaitu Balikpapan Syu serta Tarakan Syu. Kedua, Balikpapan Syu terdiri atas dua ken (kabupaten), yaitu Balikpapan dan Samarinda, sedangkan Tarakan Syu terdiri atas dua ken, yaitu Tarakan dan Berau. Ketiga, Balikpapan Ken membawahi satu bunken (subkabupaten), yaitu Pasir, sedangkan Samarinda Ken membawahi tiga bunken, yaitu Seibu Kutai, Kami Mahakam, dan Sangkulirang. Di sisi lain, Tarakan Ken membawahi tiga bunken, yaitu Bulungan, Malinau, dan
Apo Kayan, sedangkan Berau Ken tidak membawahi bunken apa pun. Keempat, Pasir Bunken membawahi dua gun (distrik), yaitu Pasir Utara dan Sampahan, serta dua fuku gun (subdistrik), yaitu Pasir Selatan dan Pasir Hulu. Di sisi lain, Bunken Seibu Kutai membawahi dua gun, yaitu Kutai Timur dan Kutai Barat. Berau Ken membawahi dua fuku gun, yaitu Gunung Tabur dan Sambaliung (Anonim 1992:210).

Setelah Jepang menyerah kepada Sekutu pada 15 Agustus 1945 dan Indonesia memproklamasikan kemerdekaannya pada 17 Agustus 1945, wilayah Kalimantan Timur menjadi bagian dari Provinsi Kalimantan yang beribu kota di Banjarmasin. Provinsi ini merupakan satu dari delapan provinsi awal di Indonesia yang ditetapkan Panitia Persiapan Kemerdekaan Indonesia (PPKI) pada 19 Agustus 1945. Gubernur Ir. Pangeran Mohamad Noor ditunjuk sebagai pemimpin pertama provinsi ini (Riwut 1979:44, 96; Soemargono dkk. 1992:1-3).

Akan tetapi, hal itu tidak berlangsung lama. Belanda melalui NICA (Netherlands Indies Civil Administration) berusaha kembali menjajah Indonesia. Kalimantan pun diduduki kembali oleh Belanda. Wilayah Kalimantan Timur dijadikan sebagai sebuah keresidenan per 1 Januari 1946 yang terdiri atas dua afdeeling, yaitu Afdeeling Kutai dan Pasir dengan ibu kota Balikpapan serta Afdeeling Bulungan dan Berau dengan ibu kota Tarakan. Tidak sampai di situ, 
Belanda juga membentuk Federasi Kalimantan Timur (FKT) yang merupakan gabungan sejumlah kesultanan yang berstatus sebagai daerah swapraja, yaitu Kutai, Bulungan, Sambaliung, Gunung Tabur, dan Pasir (Anonim 1992:113-14).

Upaya Belanda tersebut tidak berlangsung lama. Pasca-pengakuan kedaulatan pada 27 Desember 1949, sejumlah wilayah menyatakan diri bergabung ke dalam Republik Indonesia, salah satunya Kalimantan Timur. FKT pun dibubarkan. Sejak 10 April 1950, Kalimantan Timur resmi menjadi bagian dalam Republik Indonesia. Meski telah bergabung, keberadaan sejumlah kesultanan atau daerah swapraja tetap diakui, yaitu Kutai, Bulungan, dan Berau (yang meliputi Sambaliung dan Gunung Tabur). Pengakuan ini menyebabkan perubahan status daerah swapraja menjadi daerah istimewa setingkat kabupaten berdasarkan Surat Keputusan Gubernur Kalimantan Nomor 186/OPB/92/14 tertanggal 14 Agustus 1950 yang kemudian diperkuat dalam UU Darurat Nomor 2 Tahun 1953 tentang Pembentukan Daerah Otonom Propinsi Kalimantan serta UU Darurat Nomor 3 Tahun 1953 tentang Pembentukan (Resmi) Daerah Otonom Kabupaten/Daerah Istimewa Tingkat Kabupaten dan Kota Besar dalam Lingkungan Propinsi Kalimantan (Anonim 1992:130; Indonesia 1953a, 1953b).

Pengakuan atas daerah swapraja ini tidak terlepas dari upaya desentralisasi yang telah dilakukan pemerintah Republik Indonesia berdasarkan UU Nomor 22 Tahun 1948 tentang Pemerintahan Daerah yang mana merupakan penegasan atas UU Nomor 1 Tahun 1945 tentang Peraturan mengenai Kedudukan Komite Nasional Daerah. Berdasarkan UU tersebut, Republik Indonesia terbagi dalam dua macam daerah otonom, yaitu provinsi dan daerah istimewa setingkat provinsi. Di bawah provinsi atau daerah istimewa setingkat provinsi, terdapat kabupaten, kota besar, dan daerah istimewa setingkat kabupaten (The 1993:97-98, 199).

UU Darurat Nomor 2 Tahun 1953 kemudian dicabut dengan UU Nomor 25 Tahun 1956 tentang Pembentukan Daerah-Daerah Otonom Propinsi Kalimantan Barat, Kalimantan Selatan, dan Kalimantan Timur yang berlaku per 1 Januari 1957 (Indonesia 1956). Provinsi Kalimantan Timur beribu kota di Samarinda yang terdiri atas tiga daerah istimewa setingkat kabupaten, yaitu (1) Kutai, (2) Berau, dan (3) Bulungan, sebagaimana UU Darurat Nomor 3 Tahun 1953 (Riwut 1979:3637). Tiga tahun kemudian, UU Nomor 27 Tahun 1959 ditetapkan, yang mana menambah pembagian wilayah di Provinsi Kalimantan Timur, yaitu satu daerah istimewa setingkat kabupaten (Pasir) dan dua kotapraja (Balikpapan dan Samarinda) (Indonesia 1959; The 1994:141-42).

Pada masa Orde Baru, istilah daerah istimewa setingkat kabupaten diganti menjadi "kabupaten" serta 
kotapraja menjadi "kotamadya" melalui UU Nomor 5 Tahun 1974 tentang Pokok-Pokok Pemerintahan di Daerah (The 1995:90-93). Dengan demikian, jumlah kabupaten dan kotamadya di Provinsi Kalimantan Timur tidak berubah, yaitu empat kabupaten dan dua kotamadya. Perubahan baru terjadi pada 1988, yaitu terdapat "pembantu gubernur" dan "pembantu bupati" dalam struktur organisasi pemerintahan daerah Provinsi Kalimantan Timur. Pembantu gubernur meliputi dua wilayah, yaitu wilayah selatan yang melingkupi Kotamadya Samarinda, Kotamadya Balikpapan, Kabupaten Kutai, Kota Administratif (Kotif) Bontang, dan Kabupaten Pasir serta wilayah utara yang melingkupi Kabupaten Berau, Kabupaten Bulungan, dan Kota Administratif (Kotif) Tarakan. Selain itu, pembantu bupati terdapat dalam tiga kabupaten, yaitu Kutai (Kutai Pantai dan Kutai Ulu), Pasir (Pasir Utara dan Pasir Selatan), serta Bulungan (Nunukan dan Tanah Tidung) (Anonim 1992:215-16).

Menjelang berakhirnya Orde Baru, Kotamadya Tarakan dibentuk melalui UU Nomor 29 Tahun 1997 tentang Pembentukan Kotamadya Daerah Tingkat II Tarakan (Indonesia 1997). Dengan demikian, hingga akhir Orde Baru pada 1998, Provinsi Kalimantan Timur terdiri atas tiga kotamadya (Samarinda, Balikpapan, dan Tarakan), satu kotif (Bontang), dan empat kabupaten (Kutai, Pasir, Berau, dan Bulungan).
Berdasarkan latar belakang di atas, rumusan masalah dalam penelitian ini adalah dinamika historis pembentukan Provinsi Kalimantan Utara. Beberapa pertanyaan penelitian yang diajukan adalah sebagai berikut. Pertama, apa hubungan pembentukan Provinsi Kalimantan Utara dengan semangat otonomi daerah pasca-Reformasi 1998? Kedua, apa hasil pengkajian multidimensional yang mendukung pembentukan Provinsi Kalimantan Utara? Ketiga, bagaimana proses politik yang terjadi, baik di tingkat pusat maupun daerah, untuk mewujudkan pembentukan Provinsi Kalimantan Utara?

Ruang lingkup penelitian terdiri atas cakupan spasial dan temporal. Cakupan spasial adalah sebagian wilayah Provinsi Kalimantan Timur yang kemudian bergabung dalam Provinsi Kalimantan Utara. Cakupan temporal adalah sejak 1999, yaitu tahun penetapan UU Nomor 22 Tahun 1999 tentang Pemerintahan Daerah hingga 2012, yaitu tahun penetapan UU Nomor 20 Tahun 2012 tentang Pembentukan Provinsi Kalimantan Utara.

Tujuan penelitian ini adalah (1) untuk menunjukkan hubungan antara pembentukan Provinsi Kalimantan Utara dengan semangat otonomi daerah pasca-Reformasi 1998, (2) untuk menganalisis hasil pengkajian multidimensional yang mendukung pembentukan Provinsi Kalimantan Utara, serta (3) untuk menjabarkan secara kronologis proses politik, baik di tingkat pusat maupun daerah, untuk 
mewujudkan pembentukan Provinsi Kalimantan Utara.

Sejumlah tulisan tentang Kalimantan Timur atau Kalimantan Utara digunakan dalam penelitian ini. Sejarah pemerintahan telah dikaji dan hasilnya diterbitkan Pemerintah Daerah Tingkat I Provinsi Kalimantan Timur (1992). Sebelumnya, tulisan Tjilik Riwut $(1958 ; 1979)$ telah memberikan penjelasan singkat tentang sejarah Kalimantan secara umum maupun Kalimantan Timur secara khusus. Di samping itu, sejarah ekonomi Kalimantan Timur telah dikaji Mubyarto dkk. (1991) dan Mubyarto (2001), baik sebelum maupun sesudah Reformasi 1998. Situasi daerah perbatasan Kalimantan Timur yang kemudian menjadi Kalimantan Utara juga menimbulkan dinamika sosialpolitik tersendiri, sebagaimana dikaji Riwanto Tirtosudarmo (2005), Robert Siburian (2005), Soewarsono (2005), Mustafa Abubakar (2006), dan Tri Ratnawati (2006).

\section{B. METODE}

Penelitian ini menggunakan metode penelitian sejarah yang menekankan studi pustaka. Setelah menentukan topik melalui latar belakang, rumusan masalah, dan ruang lingkup penelitian, sumber-sumber dikumpulkan. Sumber primer dalam penelitian ini berupa peraturan/keputusan resmi dan kajian sezaman. Sumber sekunder yang digunakan dalam penelitian ini berupa referensi pendukung. Setelah itu, sumber-sumber tersebut diverifikasi dan diinterpretasi sehingga menghasilkan fakta-fakta historis. Pada akhirnya, sejumlah fakta historis disusun sehingga menghasilkan sebuah konstruksi historis yang kronologis dan komprehensif.

\section{HASIL DAN BAHASAN \\ 1. Semangat Otonomi Daerah}

Ketika Orde Baru runtuh dan Reformasi 1998 bergulir, salah satu hal yang diperjuangkan adalah desentralisasi dalam wujud otonomi daerah. Desentralisasi tidak terlepas dari praktik sentralisasi yang sangat kentara selama Orde Baru berkuasa. Dalam kesaksiannya, Presiden Bacharuddin Jusuf (B.J.) Habibie (2006:484-86) menyebutkan bahwa jargon "Trilogi Pembangunan" selama Orde Baru berkuasa tidak menyebar secara merata ke seluruh pelosok Indonesia. Walhasil, terjadilah ketimpangan atau kesenjangan antarwilayah. Oleh sebab itu, ia menaruh perhatian besar dan menganggap desentralisasi semakin penting karena beberapa alasan, seperti mendekatkan rakyat kepada pengambil keputusan, mencegah gerakan separatisme, dan dapat meningkatkan pertumbuhan ekonomi di daerah akibat peningkatan partisipasi masyarakat dalam proses pembangunan. Senada dengan hal itu, Cornelis Lay (2011:17) menyatakan bahwa pemberian otonomi secara luas kepada daerah-daerah merupakan salah satu "resep politik" penting untuk mencapai stabilitas sekaligus membuka peluang terhadap demokratisasi. 
Meski demikian, Riant Nugroho Dwidjowijoto (2000:48) menyatakan desentralisasi atau otonomi daerah bagaikan pisau bermata dua dalam kerangka Negara Kesatuan Republik Indonesia. Di satu sisi, penyelenggaraan pemerintahan daerah yang terdesentralisasi menyebabkan kemandirian semakin meningkat. Namun, di sisi lain, bentuk negara kesatuan dapat terancam dengan tuntutan desentralisasi dan otonomi dalam derajat yang lebih tinggi.

Meskipun ancaman "otonomi dalam derajat yang lebih tinggi" atau seringkali disebut sebagai wacana federalisme mengemuka, upaya desentralisasi atau otonomi daerah memiliki rasionalitas berdasarkan pengalaman penyelenggaraan pemerintahan daerah di Indonesia selama ini. Syaukani, Afan Gaffar, dan Ryaas Rasyid (2012:36-45) menyebutkan sekurang-kurangnya terdapat lima alasan, yaitu sebagai berikut. Pertama, persiapan ke arah federasi Indonesia masih belum memungkinkan. Kedua, pilihan otonomi luas merupakan pilihan yang sangat strategis dalam rangka memelihara keutuhan negara-bangsa. Ketiga, sentralisasi atau dekonsentrasi terbukti gagal mengatasi krisis nasional. Keempat, pemantapan demokrasi politik. Kelima, pemenuhan asas keadilan.

Otonomi daerah sejatinya bukan "barang baru" di Indonesia. Sejak Indonesia merdeka, sejumlah UU dan peraturan lainnya telah dikeluarkan untuk mewujudkan otonomi daerah. Ketika Orde Baru berkuasa, praktik otonomi daerah telah diamanatkan dalam UU Nomor 5 Tahun 1974 tentang Pokok-Pokok Pemerintahan di Daerah. Meski demikian, hal tersebut tidak benar-benar terlaksana, atau dilaksanakan dengan "setengah hati". Pratikno (2011:35-41) menyebutnya sebagai bentuk "keberhasilan semu" atau "desentralisasi semu" ala Orde Baru.

Oleh sebab itu, dalam era kepemimpinannya yang singkat dan transitif, Presiden B.J. Habibie menggolkan UU Nomor 22 Tahun 1999 tentang Pemerintahan Daerah dan UU Nomor 25 Tahun 1999 tentang Perimbangan Keuangan antara Pemerintah Pusat dan Daerah (Indonesia 1999a, 1999b). Kedua UU ini menggantikan UU Nomor 5 Tahun 1974 dan dianggap membawa angin segar bagi perkembangan desentralisasi dan otonomi daerah di Indonesia. Salah satu dampak keberadaan UU ini adalah perubahan paradigma yang besar terhadap manajemen pemerintahan, yaitu tidak lagi top-down, tetapi bottom-up, sehingga dipandang sangat demokratis (Dwidjowijoto 2000:78-79, 82).

Dengan ditetapkannya dua UU tersebut, aspirasi pemekaran atau peningkatan status daerah otonom yang lebih tinggi mulai disuarakan masyarakat di banyak daerah. Hal ini dapat dilihat dari pembentukan sejumlah kabupaten dan kota baru di Provinsi Kalimantan Timur. Pada tahun 
yang sama, Kabupaten Kutai dan Bulungan mengalami pemekaran daerah. Kabupaten dan kota baru yang dibentuk adalah Kabupaten Nunukan dan Kabupaten Malinau yang merupakan pemekaran Kabupaten Bulungan, Kabupaten Kutai Barat dan Kabupaten Kutai Timur yang merupakan pemekaran Kabupaten Kutai, serta Kota Bontang. Hal ini termaktub dalam UU Nomor 47 Tahun 1999 tentang Pembentukan Kabupaten Nunukan, Kabupaten Malinau, Kabupaten Kutai Barat, Kabupaten Kutai Timur, dan Kota Bontang tertanggal 4 Oktober 1999 (Indonesia 1999c). Jika ditelusuri lebih lanjut, kabupaten dan kota baru tersebut merupakan peningkatan status atas beberapa wilayah "pembantu bupati" serta kota administratif pada periode sebelumnya.

Pembentukan kabupaten baru di Provinsi Kalimantan Timur setelah Reformasi 1998 juga terjadi pada 2007. Hal ini tidak terlepas dari pembaharuan dua UU terkait otonomi daerah, yaitu UU Nomor 32 Tahun 2004 tentang Pemerintahan Daerah serta UU Nomor 33 Tahun 2004 tentang Perimbangan Keuangan antara Pemerintah Pusat dan Pemerintah Daerah. Kabupaten baru yang dibentuk adalah Kabupaten Tana Tidung yang merupakan pemekaran dari Kabupaten Bulungan berdasarkan UU Nomor 34 Tahun 2007 tentang Pembentukan Kabupaten Tana Tidung di Provinsi Kalimantan Timur tertanggal 10 Agustus 2007 (Indonesia 2007).

\section{Pengkajian Multidimensional}

Dengan semangat desentralisasi dan otonomi daerah, aspirasi pemekaran menjadi sebuah provinsi baru oleh masyarakat Provinsi Kalimantan Timur memerlukan kajian yang mendalam. Pembentukan Provinsi Kalimantan Utara pun oleh sejumlah kalangan dianggap penting karena beberapa hal krusial, seperti aspek sosial-ekonomi, pengelolaan sumber daya alam (SDA), pertahanan-keamanan, dan kewilayahan. Dengan kajian atas aspek-aspek tersebut, pembentukan Provinsi Kalimantan Utara memperoleh "legitimasi ilmiah" untuk segera dibawa ke dalam proses politik yang cukup panjang.

Pertama, aspek sosial-ekonomi. Sebelum memekarkan diri, Provinsi Kalimantan Timur memiliki sejumlah persoalan ekonomi yang pelik. Sejak 1990-an, sejumlah kalangan telah menyoroti keadaan sosial-ekonomi Provinsi Kalimantan Timur yang perlu mendapat perhatian lebih lanjut, terutama dari pemerintah pusat. H.M. Ardans (1992:226) menyatakan bahwa Provinsi Kalimantan Timur mempunyai struktur perekonomian yang potensial sekaligus mengandung bahaya. Alasannya, kekayaan provinsi ini, terutama bahan tambang dan hasil hutan merupakan komoditas strategis dalam pasaran dunia. Di sisi lain, kekayaan ini menimbulkan bahaya, sebab banyak enclave akan timbul yang kemudian berdampak pada pertumbuhan ekonomi yang tidak merata dan seimbang. 
Tidak hanya dalam persoalan makro di tingkat provinsi, persoalan sosial-ekonomi yang cukup disoroti juga adalah persoalan di daerah perbatasan. Mubyarto dkk. (1991:1012) menyatakan bahwa persoalan pemenuhan tiga kebutuhan dasar, yaitu pangan, kesehatan, dan pendidikan harus menjadi prioritas pemerintah untuk daerah-daerah perbatasan, seperti Nunukan, Krayan, dan Kayan Hulu. Hal ini disimpulkan Sulistiyo (1992:96-97) bahwa masyarakat daerah perbatasan tersebut memiliki tingkat kesejahteraan yang rendah akibat infrastruktur (jaringan komunikasi dan transportasi) yang buruk. Oleh sebab itu, ia menyebut rendahnya tingkat kesejahteraan menjadi faktor pendorong penduduk untuk meninggalkan daerahnya, di samping adanya faktor penarik di luar daerah perbatasan, seperti tersedianya pasar bagi hasil pertanian, tersedianya lapangan kerja, dan sebagainya.

Setelah Reformasi 1998 bergulir, kajian sosial-ekonomi daerah-daerah yang dianggap layak memperoleh otonomi daerah semakin luas, salah satunya Provinsi Kalimantan Timur. Mubyarto (2001:56-57) menegaskan bahwa semangat otonomi daerah yang ditekankan pada tingkat kabupaten berdasarkan UU Nomor 22 Tahun 1999 menjadi "ujian berat" bagi provinsi terluas kedua setelah Papua ini akibat ketimpangan sosial-ekonomi yang parah. Oleh sebab itu, prioritas terhadap program pembangunan pedesaan, penanggulangan kemiskinan, dan pemberdayaan masyarakat menjadi "jalan terbaik". Dengan kata lain, pembangunan sumber daya manusia (SDM) menjadi kunci. Di samping itu, sistem ekonomi kerakyatan yang demokratis dapat menjadi sarana peningkatan kualitas sosial-ekonomi masyarakat. Hal ini dapat dituangkan dalam berbagai program konkret, seperti peningkatan akses terhadap aset produksi, penguatan proses transisi dan kemitraan usaha ekonomi rakyat, peningkatan pelayanan pendidikan dan kesehatan, penguatan industri rakyat, peningkatan tumbuhnya tenaga kerja mandiri, pemerataan pembangunan antardaerah, serta penerbitan peraturan perundang-undangan yang melindungi dan mendukung pengembangan ekonomi rakyat. Dengan demikian, kesinambungan pembangunan jangka panjang dapat terjaga.

Setelah pemekaran sejumlah kabupaten di Provinsi Kalimantan Timur pada 1999, Kabupaten Nunukan mendapat perhatian akibat statusnya sebagai daerah perbatasan. Salah satunya adalah persoalan tenaga kerja Indonesia (TKI) yang menjadikan Nunukan sebagai daerah transit. Hal ini tidak terlepas dari peluang lapangan pekerjaan dan penghidupan yang lebih baik di negeri tetangga, yaitu Tawau di Sabah, Malaysia. Hal ini semakin memperlihatkan sebuah kontradiksi, atau "ketimpangan yang menganga di antara batas negara" (Tirtosudarmo 2005:180-82). Oleh sebab itu, aktivitas ekonomi daerah perbatasan, dalam hal ini Nunukan, justru ditopang bukan dari Provinsi Kalimantan Timur, melainkan 
dari Tawau, Sabah, Malaysia. Aktivitas ekonomi yang dominan di Nunukan adalah perdagangan dan jasa, yang mana berbeda dengan aktivitas ekonomi dominan di Provinsi Kalimantan Timur, yaitu pertambangan dan kehutanan (Siburian 2005:188-89, 210-11).

Hal ini dipertegas Ratnawati (2006:102-42) dalam laporannya bahwa Nunukan dihadapkan dengan sejumlah konflik kewenangan di daerah perbatasan. Ia memetakan tiga pihak yang berkonflik di dalamnya, yaitu negara, pengusaha, dan masyarakat adat. Selain itu, persoalan kelautan dan kehutanan di daerah perbatasan serta keuangan daerah juga merupakan imbas dari implementasi UU Nomor 22 Tahun 1999. Oleh sebab itu, Ratnawati merekomendasikan perlunya semacam otonomi khusus mengingat kompleksitas permasalahan di sana dengan karakteristik daerah perbatasan, di samping menegaskan kewibawaan dan kedaulatan negara.

Meski sejumlah persoalan sosialekonomi cukup pelik di Provinsi Kalimantan Timur, terdapat juga sejumlah peluang yang menjadikan provinsi ini dapat berkembang menjadi daerah otonom yang lebih baik, terutama ketika akan dimekarkan menjadi Provinsi Kalimantan Utara, seperti industri, perdagangan, penanaman modal, pertambangan dan energi, lingkungan hidup, dan pariwisata. Terkait pariwisata, potensi yang ada sangat memadai, mulai dari bentang alam yang kaya dari pedalaman hingga pesisir serta objek wisata buatan yang terbilang banyak jumlahnya (Tobing 2000:108-19).

Kedua, aspek pengelolaan SDA. Menyambung aspek pertama, aspek ini menjadi penting sebab pengelolaan SDA mendapat porsi yang besar setelah UU Nomor 22 Tahun 1999 ditetapkan. Lay (2011:22) menyebutkan bahwa hal ini menjadi peluang ekonomi yang besar bagi daerah pemilik SDA, namun sarat dengan risiko. Persoalan pengelolaan SDA di Provinsi Kalimantan Timur, terutama di daerah perbatasan, merupakan persoalan strategis yang harus mendapat perhatian khusus. Hal ini, misalnya, telah menjadi fokus pembahasan dalam seminar pada 14-15 Juli 1999 di Samarinda, tidak lama setelah UU Nomor 22 Tahun 1999 ditetapkan.

Salah satu hal yang digarisbawahi dalam seminar tersebut adalah perlunya pengakuan, penghormatan, dan jaminan atas hak-hak ulayat masyarakat adat dalam pengelolaan SDA berbasis kearifan lokal. Selain itu, prinsip lingkungan hidup harus dipenuhi dalam pengelolaan SDA yang bertanggung jawab. Dengan desentralisasi yang menjadi pintu demokratisasi, peran serta masyarakat semakin kuat dan luas, baik dalam hal perencanaan, pelaksanaan, hingga pengawasan pembangunan. Dengan demikian, keseimbangan antara eksploitasi dengan konservasi SDA serta keadilan bagi rakyat dalam akses pemanfaatan SDA dapat terwujud (Sembiring dkk. 2000:189-93). 
Ketiga, aspek pertahanankeamanan. Sebagai daerah perbatasan dengan Malaysia, sejumlah kalangan menilai pentingnya pembentukan Provinsi Kalimantan Utara dari sisi politik luar negeri dan pertahanankeamanan. Salah satu momentum yang semakin menunjukkan urgensi pembentukan Provinsi Kalimantan Utara dari sisi pertahanan-keamanan adalah aneksasi Pulau Sipadan dan Ligitan oleh Malaysia berdasarkan keputusan Mahkamah Internasional (International Court of Justice) di Den Haag, Belanda pada 17 Desember 2002 (Abubakar 2006:91).

Menurut Sarosa Hamongpranoto, peristiwa ini meninggalkan sejumlah persoalan pertahanan-keamanan di daerah perbatasan Indonesia-Malaysia untuk segera ditindaklanjuti. Tidak hanya masalah kedaulatan negara, permasalahan di daerah perbatasan yang merugikan negara, seperti penyelundupan, perdagangan manusia, pencurian ikan, hingga penjarahan hutan merupakan sejumlah isu pertahanan-keamanan yang krusial. Oleh sebab itu, ia menyatakan bahwa momentum serta sejumlah faktor pertahanan-keamanan inilah yang menyebabkan pembentukan Provinsi Kalimantan Utara menjadi sebuah keharusan (Wibisono 2010).

Keempat, aspek kewilayahan. Aspek yang dikaji secara khusus dalam disiplin ilmu wilayah ini tidak dapat diabaikan dalam studi kelayakan pembentukan (pemekaran) dan penghapusan daerah. Sebuah wilayah yang akan dibentuk harus memiliki batas-batas yang merujuk pada beberapa konsep kesatuan wilayah, seperti wilayah homogen, wilayah nodal, dan wilayah kepulauan (Hamdi dkk. 2008:54-55). Dalam hal ini, wilayah yang akan menjadi Provinsi Kalimantan Utara merupakan wilayah yang cenderung homogen dalam hal sejarah dan adat istiadat. Hal ini dapat dilacak dari wilayah Kesultanan Bulungan yang kemudian menjadi Kabupaten Bulungan dan telah dimekarkan menjadi beberapa kabupaten/kota. Meski demikian, bentang alam wilayah ini beragam, mulai dari pegunungan di daerah perbatasan darat hingga pulau dan pesisir di daerah perbatasan laut.

Hal selanjutnya yang menjadi perhatian adalah penentuan lokasi ibu kota yang mampu menunjang dua fungsi, yaitu pusat pelayanan pemerintahan dan pusat pertumbuhan wilayah. Sebagaimana penentuan batas wilayah, penentuan lokasi ibu kota juga tidak terlepas dari aspek sejarahnya (Hamdi dkk. 2008:61-63). Wilayah Provinsi Kalimantan Utara yang akan dibentuk bercikal bakal dari wilayah Kabupaten Bulungan yang beribu kota di Tanjung Selor. Dalam periode yang lebih lampau, Tanjung Selor telah menjadi ibu kota kesultanan. Wilayah ini pun telah lama dinilai sebagai wilayah strategis untuk dikembangkan sebagai ibu kota, terutama dalam hal aksesibilitas dan konektivitas antarwilayah di sekitarnya. Oleh sebab itu, Tanjung Selor dipilih sebagai calon ibu kota Provinsi Kalimantan Utara. 
Dari semua aspek yang ada, baik politik keamanan, ekonomi, sosial budaya, pendidikan, kesehatan, kesempatan kerja, hingga kewilayahan, Noveria (2017:297-317) menegaskan bahwa kehadiran dan kedaulatan negara di wilayah perbatasan merupakan hal yang utama. Oleh sebab itu, sejak 2010 pemerintah telah membentuk lembaga bernama Badan Nasional Pengelola Perbatasan (BNPP). Badan ini diharapkan menjadi motor penggerak percepatan pembangunan wilayah perbatasan, salah satunya di calon Provinsi Kalimantan Utara. Di sisi lain, kehadiran negara untuk menegaskan eksistensi kedaulatan melalui pembentukan provinsi baru ini dinilai dapat memberikan "tekanan psikologis" kepada negara tetangga. Malaysia "tentu akan memikirkan itu" ketika hendak "mengusik" Indonesia (Prasetya 2012). Dalam jangka panjang, Noor (2017:16) menyebutkan bahwa pembentukan provinsi baru ini dinilai mampu memantapkan jiwa kebangsaan atau nasionalisme "di tapal batas".

\section{Dinamika Proses Politik}

Sejumlah kajian yang mengemuka semakin menegaskan perlunya pembentukan Provinsi Kalimantan Utara. Dalam kacamata politik, Kumorotomo (2009:292) menyebutkan bahwa argumentasi yang sering dikemukakan untuk melakukan proses politik demi membentuk daerah otonom baru (DOB) adalah unsur sejarah, adat-istiadat, bahasa, dan karakteristik etnis yang berbeda, atau mungkin karena sebelumnya pernah berdiri kerajaan tersendiri. Hal ini terlihat dengan sangat jelas dalam dinamika pembentukan Provinsi Kalimantan Utara.

Berlandaskan hal tersebut, proses politik telah terjadi sekurang-kurangnya sejak terbentuknya sejumlah DOB di Provinsi Kalimantan Timur pada 1999. Sebuah gagasan untuk membentuk sebuah provinsi baru di utara wilayah Provinsi Kalimantan Timur diwujudkan dalam pembentukan Tim Panitia Persiapan Provinsi Baru Kalimantan Utara yang meliputi empat kabupaten, yaitu Berau, Bulungan, Malinau, dan Nunukan, serta satu kota, yaitu Tarakan. Bahkan, tim ini ditargetkan dapat menggolkan pembentukan Provinsi Kalimantan Utara pada 2002 (Soewarsono 2005:147-48).

Di samping itu, aspirasi pembentukan Provinsi Kalimantan Utara juga telah lahir dari kalangan sipil. Hal ini terlihat dari pembentukan sejumlah organisasi, seperti Forum Komunikasi Pelajar Mahasiswa Kaltara (termasuk Kabupaten Berau) se-Pulau Jawa dan Sulawesi terbentuk di Malang pada 13 Juni 2000 dan Tim Masyarakat Kaltara Bersatu (MKB) pada 22 November 2009 (Elu 2010).

Target yang terbilang ambisius tersebut tidak berjalan mulus. Wacana pembentukan Provinsi Kalimantan Utara kembali menyeruak pada 2005 dan Provinsi Kalimantan Timur menyatakan kesediaannya pada 2010. Perjalanan yang berliku ini terjadi karena banyak faktor, terutama 
Handep Jurnal Sejarah dan Budaya Vol. 4, No. 1, Desember 2020, hlm. 39-60

moratorium (penangguhan) pemekaran atau pembentukan DOB oleh pemerintah pusat (Anon 2011a).

Pemerintah daerah, terutama Provinsi Kalimantan Timur, telah sejak lama mendesak pemerintah pusat untuk membentuk DOB Provinsi Kalimantan Utara. Sejak 2007, kajian atas usulan ini telah disampaikan ke Dewan Perwakilan Rakyat Republik Indonesia (DPR RI) untuk dibahas lebih lanjut. Usulan ini semakin gencar disuarakan setelah pembentukan Kabupaten Tana Tidung disahkan pada tahun yang sama (Burhani 2007).

Tiga tahun berselang, proses pembentukan Provinsi Kalimantan Utara mulai menguat. Tim MKB menyambangi DPR RI dalam Rapat Dengar Pendapat Umum pada 25 Agustus 2010. Tim ini mengemukakan lima alasan penting pembentukan Provinsi Kalimantan Utara. Pertama, wilayah Kalimantan Timur sangat luas yang mengakibatkan kehadiran pemerintah belum optimal. Kedua, kesejahteraan masyarakat perbatasan masih sangat memprihatinkan. Ketiga, belum adanya keseimbangan faktor geografi, demografi, serta modal alam dan intelektual. Keempat, Provinsi Kalimantan Utara sudah merupakan kebutuhan NKRI untuk mengatasi persoalan perbatasan. Kelima, banyak penduduk Indonesia di negeri tetangga (Sabah dan Serawak) rentan atas kejahatan terhadap kemanusiaan. Lebih dari itu, Tim MKB juga menyebutkan bahwa prosedur pembentukan Provinsi Kalimantan Utara telah sesuai dengan
PP Nomor 78 Tahun 2007 yang merupakan aturan turunan dari UU Nomor 32 Tahun 2004 (Elu 2010).

Tidak hanya ke DPR RI, usulan ke Dewan Perwakilan Daerah Republik Indonesia (DPD RI) juga disampaikan untuk mencari dukungan politik agar pemerintah pusat segera membentuk provinsi ini. Luther Kombong dari Komisi Pemekaran dan Otonomi Daerah DPD RI menyatakan bahwa pembentukan Provinsi Kalimantan Utara merupakan kebutuhan mendesak yang sedapat mungkin segera terwujud karena menyangkut kedaulatan NKRI yang melingkupi daerah perbatasan RIMalaysia, terlebih setelah maraknya kasus pelanggaran kedaulatan RI oleh Malaysia, seperti merambah hutan, memindahkan patok batas, dan sebagainya (Hidayat 2010). Hal ini pun berbuah manis dengan terbitnya Keputusan DPD RI Nomor 33/DPD RI/ IV/2009-2010 tertanggal 3 Agustus 2010 tentang Pandangan dan Pendapat DPD RI terhadap Rancangan UndangUndang tentang Pembentukan Provinsi Kalimantan Utara sebagai Pemekaran dari Provinsi Kalimantan Timur (Elu 2010).

Pada 2011, aspirasi pembentukan Provinsi Kalimantan Utara semakin kuat disuarakan. Ryaas Rasyid, Menteri Negara Otonomi Daerah Indonesia periode 1999-2000 yang kemudian menjadi anggota Dewan Pertimbangan Presiden, bersama ketua dan sekretaris Tim MKB, Yusuf S.K. dan Pilipus Gaing pada 23 Maret 2011 di Jakarta mendesak pemerintah pusat agar 
memberikan prioritas pemekaran daerah di Kalimantan, juga Papua untuk mewujudkan pemerataan pembangunan antardaerah dalam bingkai NKRI (Anon 2011b).

Tidak lama berselang, sejumlah pejabat di Provinsi Kalimantan Timur kembali mendesak pemerintah pusat untuk segera membentuk Provinsi Kalimantan Utara. Walikota Tarakan, Udin Hianggio, meminta pemerintah pusat memahami bahwa pemekaran tersebut merupakan kebutuhan daerah, bukan semata-mata kepentingan politis. Senada dengan hal itu, Gubernur Kalimantan Timur, Awang Faroek Ishak, juga menyerukan bahwa pemekaran Provinsi Kalimantan Utara adalah kebutuhan. Menurutnya, Provinsi Kalimantan Timur paling siap dalam hal pembentukan DOB karena punya pengalaman pemekaran kabupaten sejak lama (Prasetya 2011a).

Menanggapi berbagai usulan pemekaran daerah, Badan Legislasi DPR RI telah mengajukan 17 calon DOB ke Komisi II DPR RI, salah satunya Provinsi Kalimantan Utara (Astria 2011). Menjelang akhir 2011, RUU Pembentukan 17 DOB inisiatif DPR RI berhasil disetujui. Bahkan, Provinsi Kalimantan Utara menjadi prioritas sebab merupakan daerah perbatasan oleh Kementerian Dalam Negeri (Kemendagri) (Karana 2011; Prasetya 2011b).

Memasuki 2012, berbagai kalangan semakin mendesak usulan pembentukan Provinsi Kalimantan Utara, salah satunya Pembina Dewan
Adat Dayak Kalimantan Timur, Yurnalis Ngayoh. Ia menyebutkan bahwa segala persyaratan telah diselesaikan dan terpenuhi sehingga hal ini tidak perlu ditunda-tunda. Senada dengan hal itu, Presiden Majelis Adat Dayak Nasional (MADN) Agustin Teras Narang juga memberikan restu atas pembentukan provinsi baru ini (Karana 2011).

Dinamika proses politik tidak hanya terjadi di tingkat pusat. Di daerah (Provinsi Kalimantan Timur), sejumlah proses politik terjadi yang tercermin pada sejumlah keputusan, baik keputusan yang dikeluarkan lembaga eksekutif (bupati dan walikota) serta lembaga legislatif (DPRD/Dewan Perwakilan Rakyat Daerah) sejak 2009 hingga 2012. Tidak kurang 55 keputusan telah dikeluarkan 12 lembaga, dengan perincian 4 Keputusan DPRD Kabupaten Bulungan (2009), 6 Keputusan Bupati Bulungan (2009), 5 Keputusan DPRD Kota Tarakan (2010), 8 Keputusan Walikota Tarakan (2010 dan 2012), 5 Keputusan DPRD Kabupaten Nunukan (2010), 2 Keputusan Bupati Nunukan (2010), 4 Keputusan DPRD Kabupaten Malinau (2009), 7 Keputusan Bupati Malinau (2009), 4 Keputusan DPRD Kabupaten Tana Tidung (2009), 4 Keputusan Bupati Tana Tidung (2010), 5 Keputusan DPRD Provinsi Kalimantan Timur (2010), dan 1 Keputusan Gubernur Kalimantan Timur (2010) (Indonesia 2012:18-22).

Meskipun proses politik di legislatif, baik DPR RI maupun DPD 
RI, terbilang lancar, tidak sedikit pihak yang meragukan pembentukan provinsi baru ini. Hetifah Syaifudian, anggota Komisi X DPR RI dari Daerah Pemilihan Kalimantan Timur, misalnya, belum terlalu pro atau setuju terhadap Kalimantan Utara pada awalnya sebab pengalaman pemekaran daerah pada periode sebelumnya tidak membawa dampak yang signifikan. Seringkali alasan politis lebih mengemuka dibanding alasan kebutuhan daerah. Di samping itu, Mokka, Ketua Badan Permusyawaratan Desa (BPD) Sei Limau, Kecamatan Sebatik Tengah, Kabupaten Nunukan, menegaskan bahwa jangan sampai pembentukan Kalimantan Utara hanya menguntungkan segelintir elite sehingga yang terjadi adalah "Kalut" (singkatan lain untuk Kalimantan Utara, yang berarti "kacau") (Prasetya 2012).

Setelah melalui dinamika proses politik yang panjang, akhirnya pada 25 Oktober 2012, dalam rapat paripurna DPR RI, UU Nomor 20 Tahun 2012 tentang Pembentukan Provinsi Kalimantan Utara disahkan. Dalam rapat paripurna tersebut, sejumlah DOB disahkan, termasuk Provinsi Kalimantan Utara. Provinsi ini pun menjadi provinsi ke-34 di Indonesia. Walikota Tarakan, Udin Hianggio, yang menghadiri rapat paripurna tersebut bersyukur atas pengesahan pembentukan provinsi baru ini. Perjuangan sejak 2001 terbayar setelah 11 tahun lamanya. Tidak hanya itu, Ketua Tim MKB, Yusuf S.K., juga akan memantau proses pembentukan pemerintahan definitif di sana sehingga diharapkan mindset pemerintah kota, kabupaten, dan DPRD semata-mata untuk kesejahteraan masyarakat dengan pembentukan Provinsi Kalimantan Utara ini (Junisah 2012).

Dengan telah disahkannya pembentukan Provinsi Kalimantan Utara, Ketua Komisi II DPR RI, Agun Gunanjar, berharap bahwa pencaplokan pulau oleh negara tetangga, Malaysia, tidak akan terjadi kembali. Harapan senada juga diungkapkan Agung Wadhyudinata, anggota DPRD Kabupaten Bulungan. Ia bersama 50 orang masyarakat Kalimantan Utara turut hadir dalam rapat paripurna tersebut dan menyambut gembira pengesahan ini sebagai buah atas apa yang telah mereka perjuangkan selama ini. Ia berharap bahwa hal ini dapat memacu tingkat kesejahteraan masyarakat di Kalimantan Utara, juga memperpendek jangkauan pelayanan pemerintah kepada masyarakat, terlebih dengan status Provinsi Kalimantan Utara sebagai provinsi yang berbatasan langsung dengan Malaysia. Di samping itu, Agung meyakini bahwa pembentukan Provinsi Kalimantan Utara mampu meningkatkan harkat dan martabat masyarakat Kalimantan Utara maupun masyarakat Indonesia pada umumnya (Anon 2012).

Satu bulan setelahnya, UU Nomor 20 Tahun 2012 tentang Pembentukan Provinsi Kalimantan Utara disahkan Presiden Susilo Bambang Yudhoyono pada 16 November 2012 dan 
diundangkan keesokan harinya. Dengan demikian, pembentukan Provinsi Kalimantan Utara dinyatakan sah secara hukum (Indonesia 2012).

\section{SIMPULAN}

Pembentukan Provinsi Kalimantan Utara tidak terlepas dari semangat desentralisasi dan otonomi daerah yang diperjuangkan dalam Reformasi. Dua UU diterbitkan pada 1999, yaitu UU Nomor 22 Tahun 1999 tentang Pemerintahan Daerah dan UU Nomor 25 Tahun 1999 tentang Perimbangan antara Pemerintah Pusat dan Daerah. Dengan dua UU ini, beberapa daerah otonom baru (DOB) di Provinsi Kalimantan Timur lahir melalui UU Nomor 47 Tahun 1999 tentang Pembentukan Kabupaten Nunukan, Kabupaten Malinau, Kabupaten Kutai Barat, Kabupaten Kutai Timur, dan Kota Bontang serta melalui UU Nomor 34 Tahun 2007 tentang Pembentukan Kabupaten Tana Tidung di Provinsi Kalimantan Timur.

Selain itu, pengkajian multidimensional telah memberikan legitimasi ilmiah bagi pembentukan Provinsi Kalimantan Utara. Paling tidak, empat aspek menjadi sorotan mengapa Provinsi Kalimantan Utara menjadi penting untuk segera dibentuk. Pertama, aspek sosial-ekonomi. Persoalan sosial-ekonomi di Provinsi Kalimantan Timur sebagai provinsi terluas kedua setelah Papua ini sangat kompleks, terutama di daerah perbatasan Indonesia-Malaysia. Kedua, aspek pengelolaan SDA.
Segudang potensi alam, terutama potensi kehutanan dan kelautan harus memperoleh perhatian khusus, terutama di daerah perbatasan. Pelibatan masyarakat, terutama masyarakat adat, sebagai konsekuensi dari desentralisasi merupakan sebuah keharusan di dalamnya. Ketiga, aspek pertahanan-keamanan. Momentum aneksasi Pulau Sipadan dan Ligitan pada 2002 menyebabkan usulan pembentukan Provinsi Kalimantan Utara untuk menjaga kedaulatan negara semakin mendesak. Keempat, aspek kewilayahan. Provinsi Kalimantan Utara memiliki karakteristik daerah perbatasan dengan bentang alam yang beragam serta warisan sejarah atasnya. Berbagai faktor tersebut bermuara pada pentingnya kehadiran dan kedaulatan negara di wilayah perbatasan sehingga jiwa kebangsaan atau nasionalisme semakin terbangun mulai dari garis terdepan.

Pengkajian multidimensional telah mengilhami dinamika proses politik yang berjalan lebih dari satu dekade. Wacana pembentukan Provinsi Kalimantan Utara telah bergulir pascapemekaran sejumlah DOB di Provinsi Kalimantan Timur pada 1999, baik dari kalangan pemerintah maupun masyarakat sipil. Hal ini pun menuai rintangan, terutama dari pemerintah pusat yang memberlakukan moratorium pembentukan DOB. Dinamika di tingkat daerah telah menunjukkan aspirasi pemerintah dan masyarakat yang semakin kuat untuk membentuk sebuah provinsi baru, 
Handep Jurnal Sejarah dan Budaya Vol. 4, No. 1, Desember 2020, hlm. 39-60

sebagaimana tercermin dalam sejumlah keputusan lembaga legislatif dan eksekutif sejak 2009 hingga 2012. Dengan hal tersebut, sejak 2007 usulan tersebut telah dibahas bersama DPR dan DPD RI. Pada 2011, wacana ini semakin mengemuka dan memuncak. Akhirnya, pada 25 Oktober 2012, UU Nomor 20 Tahun 2012 tentang Pembentukan Provinsi Kalimantan Utara disahkan dalam rapat paripurna DPR RI. Meski diliputi keraguan dari sejumlah pihak, UU ini pun tetap disambut dengan gembira sebagai salah satu langkah meningkatkan kesejahteraan masyarakat di Kalimantan Utara.

\section{DAFTAR SUMBER}

Abubakar, Mustafa. 2006. Menata Pulau-pulau Kecil Perbatasan: Belajar dari Kasus Sipadan, Ligitan, dan Sebatik. Jakarta: Penerbit Buku Kompas.

Anon. 2011a. "Kalimantan Utara, Daerah Segitiga..." Bola.kompas.com. Diunduh 19 Juli, $\quad 2020 \quad$ (https:// bola.kompas.com/read/2011/03/ 23/03051650/Kalimantan.Utara.. Daerah.Segitiga...?page=all).

Anon. 2011b. "Provinsi Kaltara Jangan Ditunda." Money.kompas.com. Diunduh 19 Juli, 2020 (https:// money.kompas.com/read/2011/03/ 25/03202062/provinsi.kaltara. jangan.ditunda?page $=$ all).
Anon. 2012. "DPR Sahkan Provinsi Kalimantan Utara sebagai Provinsi ke 34 Indonesia." News.detik.com. Diunduh 19 Juli, 2020 (https:// news.detik.com/berita/d-2072756/ dpr-sahkan-provinsi-kalimantanutara-sebagai-provinsi-ke-34indonesia).

Anonim. 1992. Sejarah Pemerintahan di Kalimantan Timur dari Masa ke Masa. Samarinda: Pemerintah Propinsi Daerah Tingkat I Kalimantan Timur.

Ardans, H. M. 1992. “Tinjauan Masalah Perekonomian Rakyat Kalimantan Timur." dalam Perekonomian Rakyat Kalimantan, disunting oleh Mubyarto, Sulistiyo, dan S. A. Awang. Yogyakarta: Aditya Media.

Astria, Riendy. 2011. "DPR Usulkan 17 Daerah Otonomi Baru." Nasional.kontan.co.id. Diunduh 23 September, 2020 (https:// nasional.kontan.co.id/news/dprusulkan-17-daerah-otonomi-baru1).

Burhani, Ruslan. 2007. "Pembentukan Provinsi Kalut Dibahas DPR RI." Antaranews.com. Diunduh 19 Juli, 2020 (https:// www.antaranews.com/berita/ 82458/pembentukan-provinsikalut-dibahas-dpr-ri).

Cabaton, Antoine. 2015. Jawa, Sumatra, dan Kepulauan Lain di Hindia Belanda. Yogyakarta: Ombak. 
Dwidjowijoto, Riant Nugroho. 2000. Otonomi Daerah: Desentralisasi Tanpa Revolusi (Kajian dan Kritik atas Kebijakan Desentralisasi di Indonesia). Jakarta: Elex Media Komputindo.

Elu, Kamillus. 2010. "Kalimantan Utara Calon Daerah Otonom Baru." Ahok.org. Diunduh 23 September, 2020 (http://ahok.org/ berita/kalimantan-utara-calondaerah-otonom-baru/).

Habibie, Bacharuddin Jusuf. 2006. Detik-detik yang Menentukan: Jalan Panjang Indonesia Menuju Demokrasi. Jakarta: THC Mandiri.

Hamdi, Muchlis dkk. 2008. Naskah Akademik tentang Pembentukan dan Penghapusan Daerah. Jakarta: Badan Pembinaan Hukum Nasional Departemen Hukum dan Hak Asasi Manusia RI.

Hidayat, Firman. 2010. "Pembentukan Provinsi Kalimantan Utara Tunggu Kebijakan Presiden." Nasional.tempo.co. Diunduh 19 Juli, 2020 (https:// nasional.tempo.co/read/243178/ pe mbentukan-provins ikalimantan-utara-tunggukebijakan-presiden).

Indonesia. 1953a. Undang-Undang Darurat Republik Indonesia Nomor 2 Tahun 1953 tentang Pembentukan Daerah Otonom Propinsi Kalimantan.
Indonesia. 1953b. Undang-Undang Darurat Republik Indonesia Nomor 3 Tahun 1953 tentang Pembentukan (Resmi) Daerah Otonom Kabupaten/Daerah Istimewa Tingkat Kabupaten dan Kota Besar dalam Lingkungan Propinsi Kalimantan.

. 1956. Undang-Undang Republik Indonesia Nomor 25 Tahun 1956 tentang Pembentukan Daerahdaerah Otonom Propinsi Kalimantan Barat, Kalimantan Selatan, dan Kalimantan Timur. . 1959. Undang-Undang Republik Indonesia Nomor 27 Tahun 1959 tentang Penetapan UndangUndang Darurat No. 3 Tahun 1953 tentang Perpanjangan Pembentukan Daerah Tingkat II di Kalimantan (Lembaran-Negara Tahun 1953 No. 9), sebagai Undang-Undang.

. 1997. Undang-Undang Republik Indonesia Nomor 29 Tahun 1997 tentang Pembentukan Kotamadya Daerah Tingkat II Tarakan.

- 1999a. Undang-Undang Republik Indonesia Nomor 22 Tahun 1999 tentang Pemerintahan Daerah.

. 1999b. Undang-Undang Republik Indonesia Nomor 25 Tahun 1999 tentang Perimbangan Keuangan antara Pemerintah Pusat dan Daerah. 

Vol. 4, No. 1, Desember 2020, hlm. 39-60

. 1999c. Undang-Undang Republik Indonesia Nomor 47 Tahun 1999 tentang Pembentukan Kabupaten Nunukan, Kabupaten Malinau, Kabupaten Kutai Barat, Kabupaten Kutai Timur, dan Kota Bontang.

2007. Undang-Undang Republik Indonesia Nomor 34 Tahun 2007 tentang Pembentukan Kabupaten Tana Tidung di Provinsi Kalimantan Timur. . 2012. Undang-Undang Republik Indonesia Nomor 20 Tahun 2012 tentang Pembentukan Provinsi Kalimantan Utara.

Irwin, Graham. 1986. Borneo Abad Kesembilan Belas: Kajian Mengenai Persaingan Diplomatik. Kuala Lumpur: Dewan Bahasa dan Pustaka Kementerian Pelajaran Malaysia.

Junisah. 2012. "Kalimantan Utara Disahkan Menjadi Provinsi ke-34 di Indonesia." Kaltim.tribunnews.com. Diunduh 23 September, 2020 (https:// kaltim.tribunnews.com/2012/10/ 25/kalimantan-utara-disahkanmenjadi-provinsi-ke-34-diindonesia).

Karana. 2011. "Dewan Adat Desak Bentuk Provinsi Kalimantan Utara." Nasional.tempo.co. Diunduh 23 September, 2020 (https://nasional.tempo.co/read/ 380070/dewan-adat-desak-bentuk- provinsi-kalimantan-utara/ full\&view $=$ ok).

Karim, M. Said. 2011. Mutiara Abadi (Restruksi Historis PejuangPejuang Kemerdekaan Bulungan). Tanjung Selor: Pemerintah Kabupaten Bulungan.

Kumorotomo, Wahyudi. 2009. "Pemekaran versus Kemakmuran Daerah." dalam Reformasi Birokrasi, Kepemimpinan dan Pelayanan Publik: Kajian tentang Pelaksanaan Otonomi Daerah di Indonesia, disunting oleh A. Pramusinto dan E. A. Purwanto. Yogyakarta: Gava Media.

Lay, Cornelis. 2011. "Otonomi Daerah dan Ke-Indonesiaan." dalam Kompleksitas Persoalan Otonomi Daerah di Indonesia, disunting oleh A. G. Karim. Yogyakarta: Pustaka Pelajar.

Mubyarto dkk. 1991. Kajian Sosial Ekonomi Desa-desa Perbatasan di Kalimantan Timur. Yogyakarta: Aditya Media.

Mubyarto. 2001. Prospek Otonomi Daerah dan Perekonomian Indonesia Pasca Krisis Reformasi. Yogyakarta: BPFE-Yogyakarta.

Noor, Firman. 2017. "Potret Kebangsaan di Wilayah Perbatasan: Catatan Pendahuluan." dalam Nasionalisme di Tapal Batas, disunting oleh F. Noor. Yogyakarta: Ombak. 
Noveria, Mita. 2017. "Catatan Penutup: Negara Hadir di Perbatasan namun Masih Terbatas." dalam Kedaulatan Indonesia di Wilayah Perbatasan: Perspektif Multidimensi, disunting oleh M. Noveria. Jakarta: Yayasan Pustaka Obor Indonesia.

Nurcahyani, Lisyawati dan Harto Juwono. 2017. Politik dan Ekonomi Perdagangan Bulungan Pada Abad XIX-XX (1878-1942). Yogyakarta: Kepel Press.

Prasetya, Lukas Adi. 2011a. "Provinsi Kalimantan Utara Perlu Dibentuk." Regional.kompas.com. Diunduh 19 Juli, 2020 (https:// regional.kompas.com/read/2011/ $03 / 30 / 06263980 /$ Provinsi.Kalimantan. Utara. Perlu.Dibentuk). . 2011b. "Provinsi Kaltara Jadi Prioritas Kemendagri." Tekno.kompas.com. Diunduh 23 September, 2020 (https:// tekno.kompas.com/read/2011/11/ $\begin{array}{lllllllllll}0 & 7 & / & 0 & 8 & 1 & 7 & 5 & 0 & 2 & /\end{array}$ provinsi.kaltara.jadi.prioritas. kemendagri).

. 2012. "Provinsi Kaltara atau Kalut?" Tekno.kompas.com. Diunduh 23 September, 2020 (https://tekno.kompas.com/read/ 2012 / 01 / 02 / 01524832 / provinsi.kaltara.atau.kalut?page $=$ all\#page3).
Pratikno. 2011. "Desentralisasi, Pilihan yang Tidak Pernah Final." dalam Kompleksitas Persoalan Otonomi Daerah di Indonesia, disunting oleh A. G. Karim. Yogyakarta: Pustaka Pelajar.

Ratnawati, Tri. 2006. Potret Pemerintahan Lokal di Indonesia di Masa Perubahan: Otonomi Daerah Tahun 2000-2005. Yogyakarta: Pustaka Pelajar.

Riwut, Tjilik. 1958. Kalimantan Memanggil. Djakarta: Endang. . 1979. Kalimantan Membangun. Palangka Raya: s.n.

Sembiring, Sulaiman N. dkk., eds. 2000. Menjadi Tuan di Tanah Sendiri: Menuju Desentralisasi Pengelolaan Sumberdaya Alam Kalimantan Timur. Samarinda: Yayasan WWF Indonesia, NRMP, APKSA, dan PEMDA PROPINSI KALTIM.

Siburian, Robert. 2005. "Dinamika Ekonomi Nunukan-Tawau." dalam Dari Entikong sampai Nunukan: Dinamika Daerah Perbatasan Kalimantan - Malaysia Timur (Serawak dan Sabah), disunting oleh R. Tirtosudarmo dan J. Haba. Jakarta: Pustaka Sinar Harapan.

Soemargono dkk. 1992. Profil Propinsi Republik Indonesia: Kalimantan Timur. Jakarta: Yayasan Bhakti Wawasan Nusantara. 
Soewarsono. 2005. "Kabupaten Perbatasan Nunukan: Beberapa Karakteristik." dalam Dari Entikong sampai Nunukan: Dinamika Daerah Perbatasan Kalimantan - Malaysia Timur (Serawak dan Sabah), disunting oleh R. Tirtosudarmo dan J. Haba. Jakarta: Pustaka Sinar Harapan.

Sulistiyo. 1992. "Masalah Sosial Ekonomi Pedesaan di Wilayah Perbatasan Kalimantan Timur." dalam Perekonomian Rakyat Kalimantan, disunting oleh Mubyarto, Sulistiyo, dan S. A. Awang. Yogyakarta: Aditya Media.

Syaukani, Afan Gaffar, dan Ryaas Rasyid. 2012. Otonomi Daerah dalam Negara Kesatuan. Yogyakarta: Pustaka Pelajar.

The, Liang Gie. 1993. Pertumbuhan Pemerintahan Daerah di Negara Republik Indonesia Jilid I. Yogyakarta: Liberty.

1994. Pertumbuhan Pemerintahan Daerah di Negara Republik Indonesia Jilid II. Yogyakarta: Liberty.

1995. Pertumbuhan Pemerintahan Daerah di Negara Republik Indonesia Jilid III. Yogyakarta: Liberty.

Tirtosudarmo, Riwanto. 2005. "Nunukan sebagai Wilayah Transit." dalam Dari Entikong sampai Nunukan: Dinamika Daerah Perbatasan Kalimantan -
Malaysia Timur (Serawak dan Sabah), disunting oleh R. Tirtosudarmo dan J. Haba. Jakarta: Pustaka Sinar Harapan.

Tobing, Raida L. 2000. Inventarisasi Rencana Legislasi Daerah (Relegda) Daerah Tingkat I Kalimantan Timur. Jakarta: Badan Pembinaan Hukum Nasional Departemen Kehakiman dan Hak Asasi Manusia RI. 